\title{
Long-term Soil Monitoring at U.S. Geological Survey Reference Watersheds
}

\section{Long-Term Environmental Monitoring}

Monitoring the environment by making repeated measurements through time is essential to evaluate and track the health of ecosystems (fig. 1). Long-term datasets produced by such monitoring are indispensable for evaluating the effectiveness of environmental legislation and for designing mitigation strategies to address environmental changes in an era when human activities are altering the environment locally and globally.

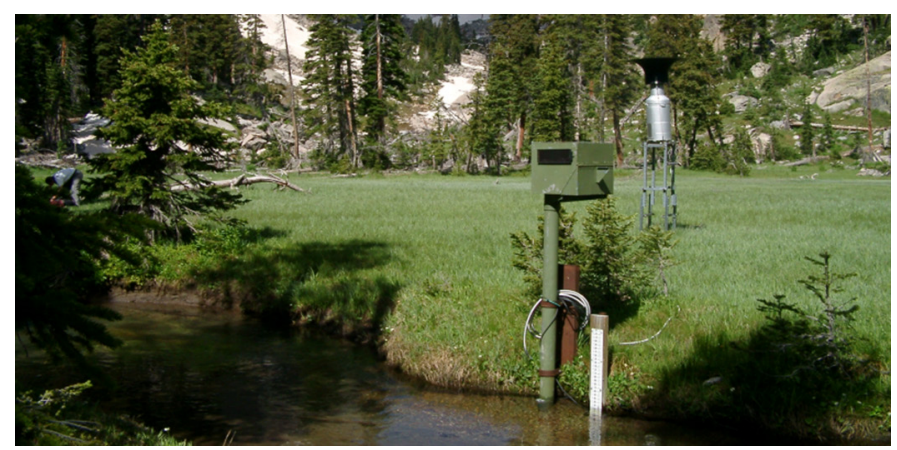

Figure 1. Photograph showing monitoring of streamflow, precipitation, and water quality at Loch Vale, Colorado.

\section{Soil Monitoring as an Emerging Science}

The importance of soil as a controlling component of terrestrial and aquatic ecosystems is well established, but the use of repeated soil sampling (or soil monitoring) to document environmental change is relatively new (Lawrence and others, 2013). Nevertheless, important physical and chemical characteristics of soils have been shown to change in less than a decade (Varallyay and others, 1990). These results have led to a growing recognition of the dynamic nature of soils and of the need to better understand the processes by which soils change and the rates at which these changes occur (Tugel and others, 2005). Recent U.S. Geological Survey (USGS) research has helped to establish soil resampling as an important environmental monitoring tool (fig. 2) by documenting the first indications of recovery in soils that had been acidified by acid rain (Lawrence and others, 2012).
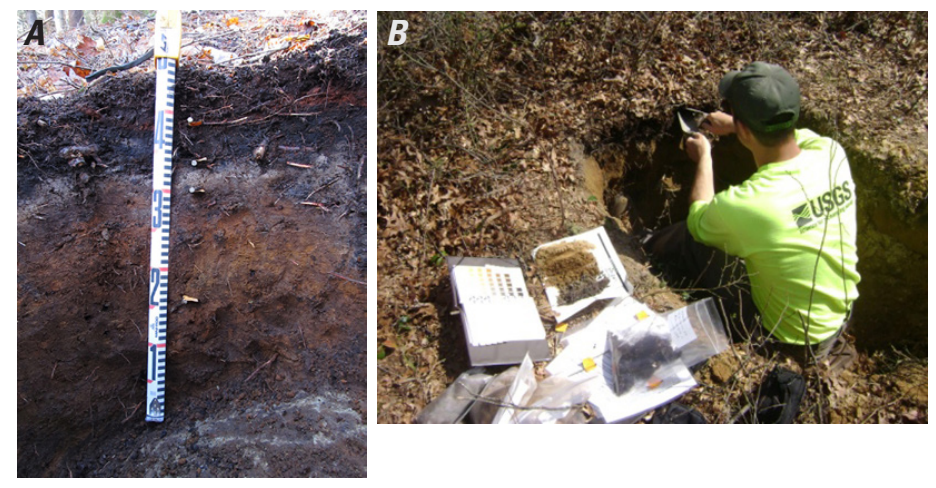

Figure 2. $A$, complex patterns of color and texture show pronounced variation in the physical and chemical characteristics of even a few centimeters of soil, Green River Watershed in Marlboro, Vermont. B, Soil scientists use standardized procedures to develop detailed descriptions of the soil profile. Photo taken in April 2012 at Riverhead, New York.

\section{Soil Monitoring in USGS Reference Watersheds}

In 1963, the USGS established the Hydrologic Benchmark Network (HBN) to monitor streamflow and water quality in minimally disturbed streams and rivers to identify natural and human-induced changes in stream health (Leopold, 1962; Murdoch and others, 2005) (fig. 3). Luna Leopold, the USGS Director who proposed the HBN, envisioned that in addition to streamflow and water quality, vegetation and soils would also be monitored and the geology characterized for each watershed (Leopold, 1962). Although HBN has focused on streamflow and water quality throughout its history, soil monitoring was added to the network in 2011.

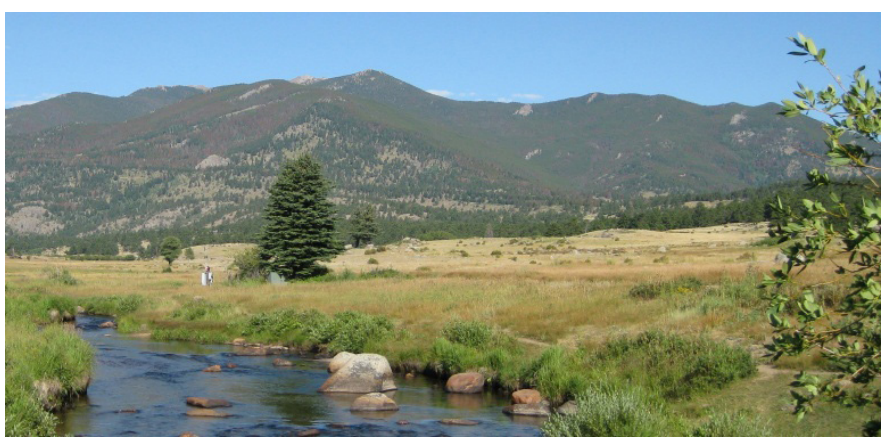

Figure 3. The eastern portion of the Big Thompson Creek watershed looking northwest, Rocky Mountain National Park, Colorado, a Hydrologic Benchmark Network watershed.

\section{The Rationale for Soil Monitoring in HBN Watersheds}

Monitoring changes in soil chemistry is a natural extension of the streamflow and water-quality monitoring that has been the basis for the HBN network because nearly all the water and chemicals deposited by the atmosphere pass through watershed soils before being delivered to streams. Soils also store most of the nutrients needed by watershed flora and fauna and therefore are an important control of overall ecosystem health (Likens and others, 1977). Although changes in soil chemistry occur slowly (during periods ranging from 2 to 3 years to as long as 2 to 3 decades) compared with changes in streamflow and water quality (which take minutes to hours), many long-term trends in streamflow and water quality occur at rates similar to those of changes in soil chemistry. As a result, soil monitoring can provide a valuable tool for interpreting trends in water quality and for assessing environmental changes in USGS reference watersheds (fig. 4).

\section{The USGS Reference Watershed Soil-Monitoring Initiative}

The USGS Reference Watershed Soil-Monitoring Initiative includes all HBN watersheds and all USGS National Water-Quality Assessment (NAWQA) reference watersheds (watersheds that are minimally affected by human activities; fig. 5). The goal of the collaborative HBN-NAWQA soil-monitoring initiative is to track changes in representative soils within each reference watershed rather than to characterize the soils throughout each watershed. Changes measured in the HBN and NAWQA reference watersheds generally would be the result of indirect human influences, such as changes in climate, fire, insect infestation, acid rain and other forms of atmospheric deposition, and natural disturbances such as forest damage from hurricanes. These watersheds primarily are on lands protected from direct human influences such as forest harvesting, agriculture, mining, and residential development. 


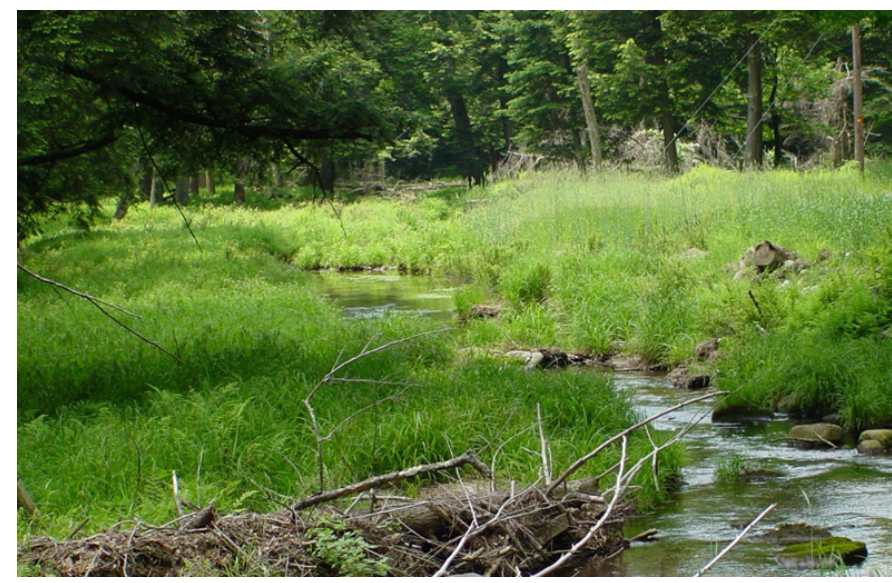

Figure 4. Soils and streams are often intimately connected in landscapes as shown by this photograph taken in the Neversink River watershed in southeastern New York State.

\section{General Sampling Strategy}

Soil sampling is being conducted once every 7 years at each of the 37 HBN watersheds and 19 NAWQA reference watersheds. There are a total of 53 sites because three of the sites belong to both networks. The seven-year sampling rotation is based on results of previous soil resampling studies that have shown key measurements such as exchangeable cations, $\mathrm{pH}$, and organic carbon change during periods of 5 to 10 years (Lawrence and others, 2013).

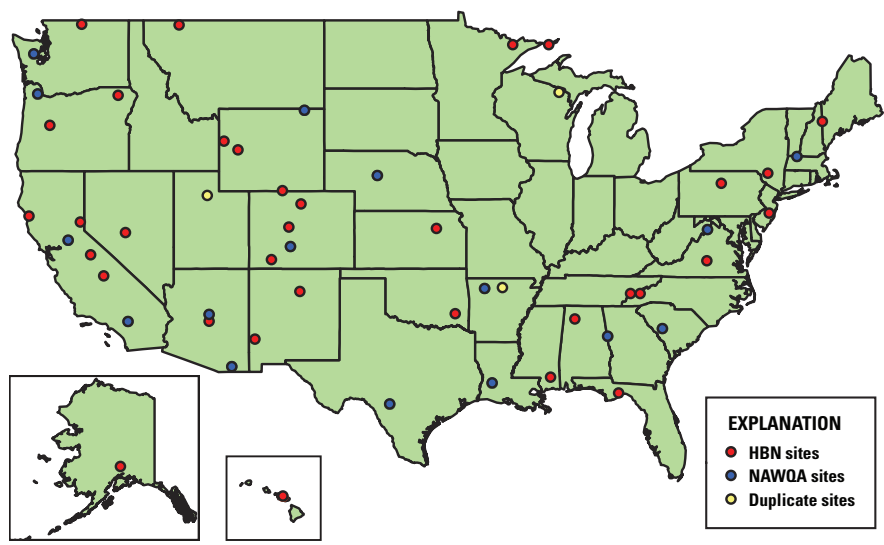

Figure 5. Map showing locations of 53 soil sampling sites: 37 Hydrologic Benchmark Network (HBN) and 19 National Water-Quality Assessment (NAWOA) reference watersheds nationwide. There are 53 total sites because three of the sites belong to both networks.

Soil samples are collected at three locations in each watershed (fig. 6) at sites selected to represent the dominant landscape types within each watershed - typically the ridgetop, midslope, and valley bottom. At each location, a central, deep pit is excavated with a hand shovel until the shovel reaches the C-horizon (unconsolidated parent material) or bedrock. For soils greater than 1.5 meters $(\mathrm{m})$ in depth, the pit is dug as deeply as time and safety allow (usually less than 2 $\mathrm{m}$ in depth). When possible, soil augers are used to sample deep soils. The soil profile is characterized and fully described using standard protocols (Schoeneberger and others, 2002), and soil samples are collected from each soil horizon for chemical analyses. In addition, at each location, six satellite pits are dug about $15 \mathrm{~m}$ from the central pit, surrounding it, to enable soil scientists to characterize the spatial variability in surficial soil properties. The satellite pits are excavated into the B-horizon (the mineral horizon characterized by its accumulation of organic matter, minerals, and inorganic chemicals), and samples are collected from all horizons identified above, including the B-horizon. All chemical analyses of soil samples are conducted in the USGS Soil and Low Ionic Strength Water-Quality Laboratory in Troy, New York, using standard techniques. Soil samples are archived after analyses.

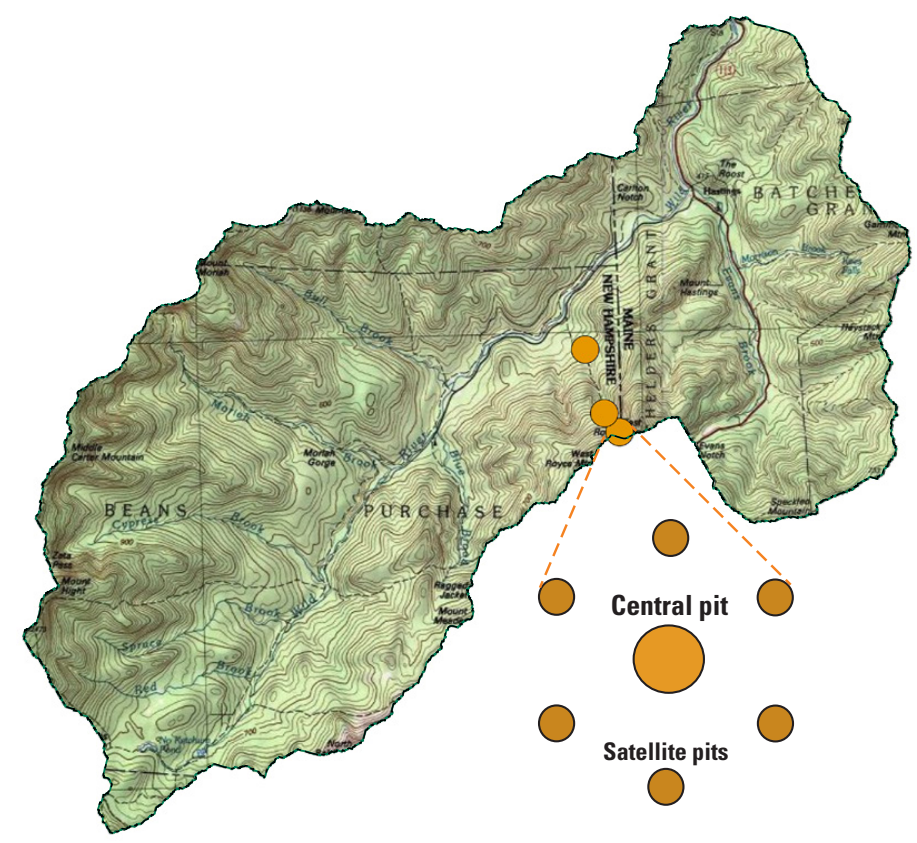

Figure 6. A map of the Wild River watershed in Maine and New Hampshire showing soil sampling locations. The inset schematic shows the sampling-point geometry at each sampling location.

\section{Status of USGS Reference Watershed Soil-Monitoring Initiative}

The soil-monitoring initiative began in 2011, and by the end of the 2013 field season, samples had been collected from 21 of the 53 reference watersheds. The first round of sampling at all HBN and NAWQA reference watersheds will be completed by the end of 2017 . In 2018, resampling will begin at the watersheds sampled in 2011. Several of the network watersheds were sampled previously through other USGS activities. Consequently, results from the soil-monitoring initiative began to be interpreted in 2013 rather than 2018 .

\section{References Cited}

Lawrence, G.B., Fernandez, I.J., Richter, D.D., Ross, D.S., Hazlett, P.W., Bailey, S.W., Ouimet, Rock, Warby, R.A.F., Johnson, A.H., Lin, H.S., Kaste, J.M., Lapenis, A.G., and Sullivan, T.J., 2013, Measuring environmental change in forest ecosystems by repeated soil sampling-A North American perspective: Journal of Environmental Quality, v. 42, p. 623-639.

Lawrence, G.B., Shortle, W.C., David, M.B., Smith, K.T., Warby, R.A.F., and Lapenis, A.G., 2012, Early indications of soil recovery from acidic deposition in U.S. red spruce forests: Soil Science Society of America Journal, v. 76, p. 1407-1417.

Leopold, L.B., 1962, A national network of hydrologic bench marks: U.S. Geological Survey Circular 460-B, 4 p.

Likens, G.E., Bormann, F.H., Pierce, R.S., Eaton, J.S., and Johnson, N.M., 1977, Biogeochemistry of a forested ecosystem (1st ed.), New York, Springer-Verlag, 159 p.

Murdoch, P.S., McHale, M.R., Mast, A.M., and Clow, D.W., 2005, The U.S. Geological Survey Hydrologic Benchmark Network: U.S. Geological Survey Fact Sheet 2005-3135, 6 p.

Schoeneberger, P.J., Wysocki, D.A., Benham, E.C., and Soil Survey Staff, 2012, Field book for describing and sampling soils, Version 3.0: Natural Resources Conservation Service, National Soil Survey Center, Lincoln, Nebr. [variously paged].

Tugel, A.J., Herrick, J.E., Brown, J.R., Mausbach, M.J., Puckett, W., and Hipple, K., 2005, Soil change, soil survey and natural resources decision making-A blueprint for action: Soil Science Society of America Journal, v. 69, p. 738-747.

Varallyay, G., Scharpenseel, H.W., and Targulian, V.O., 1990, Types of soil processes and changes, in Arnold, R.W., Szabolcs, I., and Targulian, V.O., eds., Global soil change: Laxenburg, Austria, International Institute for Applied Systems Analysis, p. 41-62.

By Michael R. McHale, Jason Siemion, Gregory B. Lawrence, and M. Alisa Mast

For further information contact:

Director, U.S. Geological Survey

New York Water Science Center

425 Jordan Road

Troy, NY 12180-8349

dc_ny@usgs.gov

or visit our Web site at: http://ny.water.usgs.gov 